\title{
Evaluation of the mass attenuation coefficient and Effective Atomic Number of the Eremurus spp. Root in Mammography Energy Range
}

\author{
Ehsan Taghizadeh Tousi ${ }^{1, *}$, Rokiah Hashim ${ }^{2}$, Sabar Bauk ${ }^{3}$, \\ Mohamad Suhaimi Jaafar ${ }^{4}$ \\ ${ }^{I}$ (University of Torbat Heydarieh, Torabat Heydarieh, Iran) \\ ${ }_{2}^{2}$ (Division of Bioresource, Paper and Coatings Technology, School of Industrial Technology, Universiti Sains \\ Malaysia, 11800 USM, Penang, Malaysia) \\ ${ }_{3}^{3}$ (Physics Section, School of Distance Education, Universiti Sains Malaysia, 11800 USM, Penang, Malaysia) \\ ${ }^{4}$ (School of Physics, Universiti Sains Malaysia, 11800 USM, Penang, Malaysia)
}

\begin{abstract}
The potential of the Eremurus spp. root as a binder in Rhizophora-Eremurus spp. particleboard mammography phantom had been approved. In this study, the potential of Eremurus spp. as a phantom material has been investigated. The effective atomic number of the Eremurus spp. was calculated as an important parameter in the low energy range. Also, the mass attenuation coefficient of the Eremurus spp. root was measured in the $16.63 \mathrm{keV}-25.30 \mathrm{keV}$ photon energy as a mammography range. Although, the effective atomic number of the Eremurus spp. was near to that of tissue, the mass attenuation of the Eremurus spp. root was not found close to those of breast tissue and water phantom. The results show that the Eremurus spp.root can be used just as a binder in phantom and it cannot be as a main phantom material.
\end{abstract}

Keywords : Effective Atomic Number, Eremurus spp., Mammography, Mass Attenuation Coefficient, XRF

\section{Introduction}

The phantom has been widely used as a simulated system in medical physics [1]. The phantom can be made from various material in different shapes [2,3]. Water is the most used as a phantom material based on similar composition with body tissue [2,4]. But, the physical properties of water causes that water phantom cannot be used in all medical and research centers [5]. The natural material such as wood has been considered as a phantom material [6-11]. The Rhizophora-Eremurus spp. particleboard has been investigated as a mammography phantom by some researchers $[2,10,12,13]$, which confirmed the potential of the RhizophoraEremurus spp. particleboard as a mammography phantom. The Eremurus spp. root was used as a binder in the Rhizophora-Eremurus spp. particleboard, which just had $5 \%$ to 15\% of the Eremurus spp. weight percentage. In this study, the potential of the Eremurus spp. root has been investigated as a main phantom material [14].

The breast is a soft organ, which is not including the dense mass such as the bone. Therefore, the lower energies of X-ray are used in the mammography to illustrate the breast diseases. A composite material contains multiple elements. During photons interaction with matter, the atomic number is one of the most important parameters $[15,16]$. The breast is a composite material that contains multiple elements. The mixture matter can be assumed as a simple matter to calculate its atomic number, which is called effective atomic number $\left(Z_{\text {eff }}\right)$. Therefore, $Z_{\text {eff }}$ of a phantom material should be firstly compared with that of tissue [13]. One of the most important parameters for a phantom is the mass attenuation coefficient in the lower energy range [12]. The mass attenuation coefficient is defined as a ratio of the linear attenuation coefficient $(\mu)$ per density of absorber material $(\rho)$. The unit of mass attenuation coefficient is $\mathrm{m}^{2} \cdot \mathrm{kg}^{-1}$ in the SI system. The mass attenuation coefficient is a more significant quantity in the attenuation properties of a material, because it offers the reduction of X-ray intensity as a function of the mass of traveled material instead of the path length as the linear attenuation [17-19]. In this study, the effective atomic number of the Eremurus spp. root was calculated and compared with those of tissue and water phantom. Then, the mass attenuation coefficient of Eremurus spp. root was measured by X-rays in $16.63 \mathrm{keV}-25.30 \mathrm{keV}$ energy range, and was compared with the theoretical values for water and young-age breast with $75 \%$ muscle and $25 \%$ fat that is called Breast $1[7,13]$ calculated by the XCOM computer program [20].

\subsection{Effective Atomic Number $\left(Z_{\text {eff }}\right)$}

\section{Materials And Methods}

The photoelectric effect is one of the most significant interaction of photons with matter in the lowenergy photon range, which is used in mammography technique [15, 21, 22]. The photoelectric effect is actively affected by the atomic number $(Z)$ or effective atomic number $\left(Z_{\text {eff }}\right)$ of the composite materials $[15,21,22]$. 
Therefore, the response of two materials with the same effective atomic number could be significantly closer together under the radiation in the low-energy range. The effective atomic number of a compound material is determined by Eq. 1 [15, 23, 24]:

$Z_{\text {eff }}=\left(\sum_{i=1}^{N}\left(\alpha_{i} Z_{i}^{m}\right)\right)^{\left(\frac{1}{m}\right)}$

where $\alpha_{i}$ and $Z_{i}$ are the electronic fraction and atomic number of the $i^{\text {th }}$ element in the composite, respectively. The experimental coefficient is called $m$ that has been evaluated to be equal 3.4 for biological materials such as water, wood, or human organs [23, 24]. Also, the electronic fraction of the $i^{\text {th }}$ element is given by Eq. 2 [15, 24]:

$\alpha_{i}=\frac{w_{i}\left(\frac{Z_{i}}{A_{i}}\right)}{\sum w_{i}\left(\frac{Z_{i}}{A_{i}}\right)}$

where, $w_{i}$ and $A_{i}$ are fractional weight and atomic mass of the $i^{\text {th }}$ element, respectively.

\subsection{Attenuation coefficient properties}

In the present study, an X-ray fluorescent (XRF) beam was used to determine the mass attenuation coefficient of the root of Eremurus spp. XRF photons were emitted from high-purity metal target that was exposed by an annular ${ }^{241} \mathrm{Am} \gamma$ source. The XRF energies from the metal targets were niobium $\left(\mathrm{K}_{\alpha}=16.63 \mathrm{keV}\right)$, molybdenum $\left(\mathrm{K}_{\alpha}=17.47 \mathrm{keV}\right)$, palladium $\left(\mathrm{K}_{\alpha}=21.26 \mathrm{keV}\right)$, silver $\left(\mathrm{K}_{\alpha}=22.17 \mathrm{keV}\right)$, and tin $\left(\mathrm{K}_{\alpha}=25.30 \mathrm{keV}\right)$. The experimental schematic diagram of XRF set-up is shown in Fig. 1.

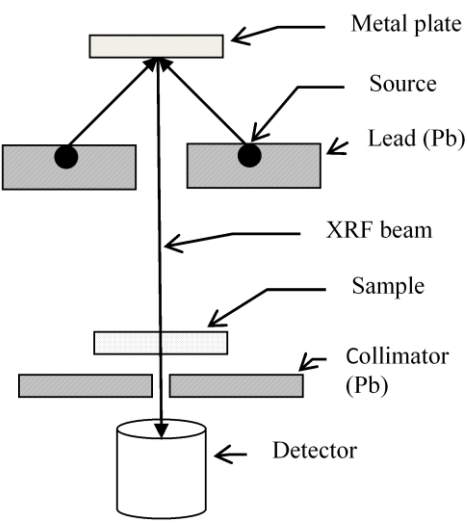

Figure 1. The experimental schematic diagram of XRF set-up to measure the attenuation coefficients of the root of Eremurus spp.

According to the Beer-Lambert law, the attenuation of a photon beam passing through a material is determined by Eq. 3 [17]:

$I=I_{0} e^{-\mu x}$

where $I$ is the transmitted photon intensity, $I_{0}$ is the primary photon intensity, $x$ is the thickness $(\mathrm{cm})$ of the sample and $\mu\left(\mathrm{cm}^{-1}\right)$ is the linear attenuation coefficient of the material. The mass attenuation coefficient is defined by Eq. 4 [12]:

$\mu=\frac{1}{x} \ln \left(\frac{I_{0}}{I}\right) \stackrel{\times(1 / \rho)}{\longrightarrow} \frac{\mu}{\rho}=\frac{1}{\rho x} \ln \left(\frac{I_{0}}{I}\right)$

where $\mu / \rho$ is the mass attenuation coefficient $\left(\mathrm{cm}^{2} \mathrm{~g}^{-1}\right)$ and $\rho x$ is called the mass density or mass thickness. The error of the mass attenuation coefficient can be determined by Eq. 5 [25]:

$\sigma_{\left(\frac{\mu}{\rho}\right)}=\left(\frac{\sigma_{(\mu)}}{\mu}+\frac{\sigma_{(\rho)}}{\rho}\right)\left(\frac{\mu}{\rho}\right)$

where $\sigma_{(\mu)}\left(\mathrm{cm}^{-1}\right)$ and $\sigma_{(\rho)}\left(\mathrm{g} \mathrm{cm}^{-3}\right)$ are the errors in the linear mass attenuation coefficient and in the density, respectively that are given by Eqs. 6 and 7 [25]: 


$$
\begin{aligned}
& \sigma_{(\mu)}= \pm\left[\left(\mu_{\text {max }}-\mu_{\text {min }}\right) / 2\right] \\
& \sigma_{(\rho)}= \pm\left[\left(\rho_{\text {max }}-\rho_{\text {min }}\right) / 2\right]
\end{aligned}
$$

Also the percentage difference of the mass attenuation coefficient is calculated by Eq. 8 [26]:

$$
\text { error } \%=\frac{(\mu / \rho)_{\text {theo }}-(\mu / \rho)_{\exp }}{(\mu / \rho)_{\text {theo }}} \times 100 \%
$$

where $(\mu / \rho)_{\exp }$ and $(\mu / \rho)_{\text {theo }}$ are the experimental and theoretical mass attenuation coefficients, respectively.

The cylindrical samples of the Eremurus spp. root were made for XRF by Carver 4350L manual hydraulic press machine with $1 \mathrm{~g} / \mathrm{cm}^{3}$ as the target density. The diameter of samples was $15 \mathrm{~mm}$ and the thicknesses were $3 \mathrm{~mm}, 6 \mathrm{~mm}, 8 \mathrm{~mm}$, and $15 \mathrm{~mm}$, approximately. Fig. 2 shows the samples used for the measurement of the mass attenuation coefficients.

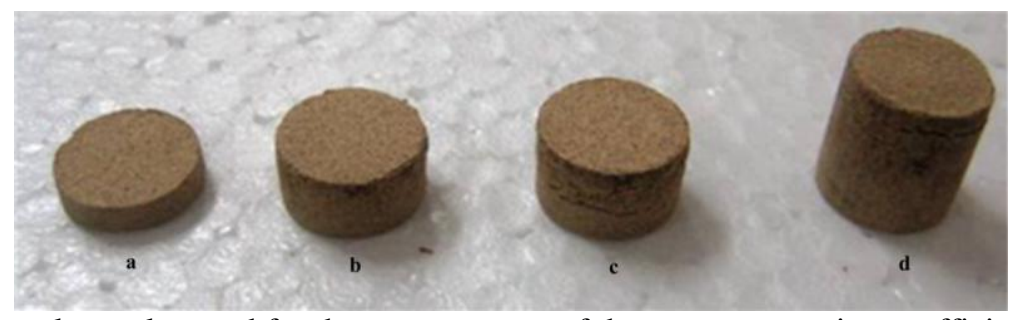

Figure 2. Experimental samples used for the measurement of the mass attenuation coefficients of the Eremurus spp. root, in four different thicknesses a $(3 \mathrm{~mm}), \mathrm{b}(6 \mathrm{~mm}), \mathrm{c}(8 \mathrm{~mm})$, and $\mathrm{d}(15 \mathrm{~mm})$.

\section{Results And Discussion}

1.3. Calculated effective atomic number of the Eremurus spp. $\operatorname{root}\left(\mathrm{Z}_{\mathrm{eff}}\right)$

The powdered Eremurus spp. root was used as the samples for FE-SEM coupled EDX. The FE-SEM micrographs and EDX results of the Eremurus spp. root is shown in Fig. 3.

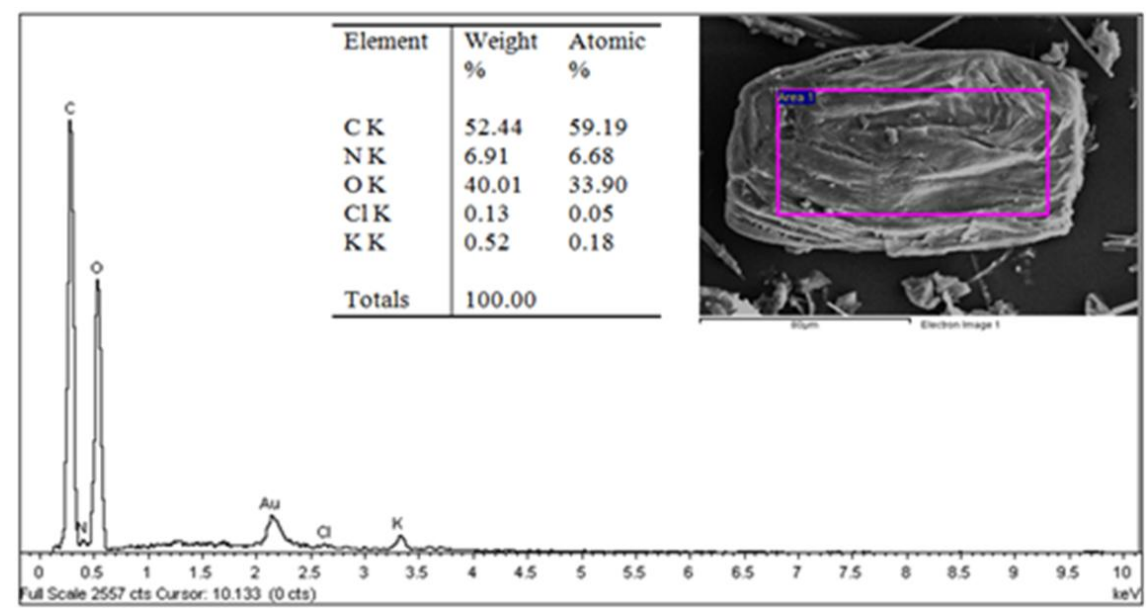

Figure 3: The FE-SEM and EDX results of the Eremurus spp. root.

The elemental composition of water [27], young-age breast :breasts 1 with 75\% muscle and 25\% fat [7], and

\begin{tabular}{|c|c|c|c|c|c|c|c|c|c|c|c|c|}
\hline \multirow[t]{2}{*}{ Composite } & \multicolumn{11}{|c|}{ Component Elements } & \multirow[t]{2}{*}{$Z_{\text {eff }}$} \\
\hline & $\mathrm{H}$ & $\mathrm{C}$ & $\mathrm{N}$ & $\mathrm{O}$ & $\mathrm{Na}$ & $\mathrm{Mg}$ & $\mathrm{P}$ & $\mathrm{S}$ & $\mathrm{Cl}$ & $\mathrm{K}$ & $\mathrm{Ca}$ & \\
\hline Water $^{\mathrm{a}}$ & 0.11 & 0.00 & 0.00 & 0.89 & 0.00 & 0.00 & 0.00 & 0.00 & 0.00 & 0.00 & 0.00 & 7.50 \\
\hline Breast $1^{b}$ & 10.70 & 28.30 & 2.63 & 57.60 & 0.06 & 0.02 & 0.15 & 0.38 & 0.06 & 0.23 & 0.01 & 7.29 \\
\hline Eremurus spp. root & & 52.44 & 6.91 & 40.01 & 0.00 & 0.00 & 0.00 & 0.00 & 0.13 & 0.52 & 0.00 & 7.36 \\
\hline
\end{tabular}
Eremurus spp. are shown in Table 1 that consists calculated $\mathrm{Z}_{\mathrm{eff}}$ values of them based in Eqs. 1 and 2.

Table 1: The elemental compositions and $\mathrm{Z}_{\mathrm{eff}}$ of water, breast 1, and Eremurus spp. root. 
The $\mathrm{Z}_{\mathrm{eff}}$ values of Eremurus spp. was found among those of water and breast 1. The percentage difference between $\mathrm{Z}_{\text {eff }}$ value of breast 1 with that of Eremurus spp. root was $0.96 \%$, which proved the potential of the Eremurus spp. root to be as a tissue-equivalent phantom material.

\subsection{Mass attenuation coefficient measurement}

The linear and mass attenuation coefficient of the root of Eremurus spp. in the photon energy range of $16.63 \mathrm{keV}-25.3 \mathrm{keV}$ is shown in Table 2, which simultaneously illustrates the XCOM calculated mass attenuation coefficients of water and young-age breast, and the difference and percentage difference of the mass attenuation coefficients of the root of Eremurus spp.

Table 2. Mass attenuation coefficients of water and Breast 1 from the XCOM computer program [20], and linear attenuation coefficient, mass attenuation coefficient, error, and percentage difference of the mass attenuation coefficients of the root of Eremurus spp.

\begin{tabular}{|l|l|l|l|l|l|l|l|}
\hline $\begin{array}{l}\text { Energy } \\
(\mathrm{keV})\end{array}$ & $\begin{array}{l}\text { Water } \\
(\mathrm{XCOM})\end{array}$ & $\begin{array}{l}\text { Breast 1 } \\
(\mathrm{XCOM})\end{array}$ & \multicolumn{5}{|l|}{ Eremurus spp. root } \\
\cline { 2 - 8 } & $\mu / \rho\left(\mathrm{cm}^{2} \mathrm{~g}^{-1}\right)$ & $\begin{array}{l}\mu \\
\left.{ }^{1}\right)\end{array}$ & $\begin{array}{l}\mu / \rho \\
\left(\mathrm{cm}^{2} \mathrm{~g}^{1}\right)\end{array}$ & $\begin{array}{l}\sigma \quad(\mu / \rho) \\
\left(\mathrm{cm}^{2} \mathrm{~g}^{-1}\right)\end{array}$ & $\begin{array}{l}\mu / \rho(\%) \text { difference } \\
\text { with water }\end{array}$ & $\begin{array}{l}\mu / \rho \\
\text { with Breast1 }\end{array}$ \\
\hline 16.63 & 1.270 & 1.160 & 2.225 & 1.866 & 0.368 & 46.93 & 60.86 \\
\hline 17.47 & 1.120 & 1.020 & 1.922 & 1.612 & 0.284 & 43.93 & 58.04 \\
\hline 21.26 & 0.706 & 0.652 & 1.196 & 0.939 & 0.174 & 33.00 & 44.02 \\
\hline 22.17 & 0.645 & 0.598 & 1.062 & 0.891 & 0.150 & 38.14 & 49.00 \\
\hline 25.30 & 0.497 & 0.466 & 0.805 & 0.675 & 0.118 & 35.81 & 44.85 \\
\hline
\end{tabular}

The mass attenuation of the root of Eremurus spp. is compared with the XCOM calculated that of water and young-age breast in Fig. 4.

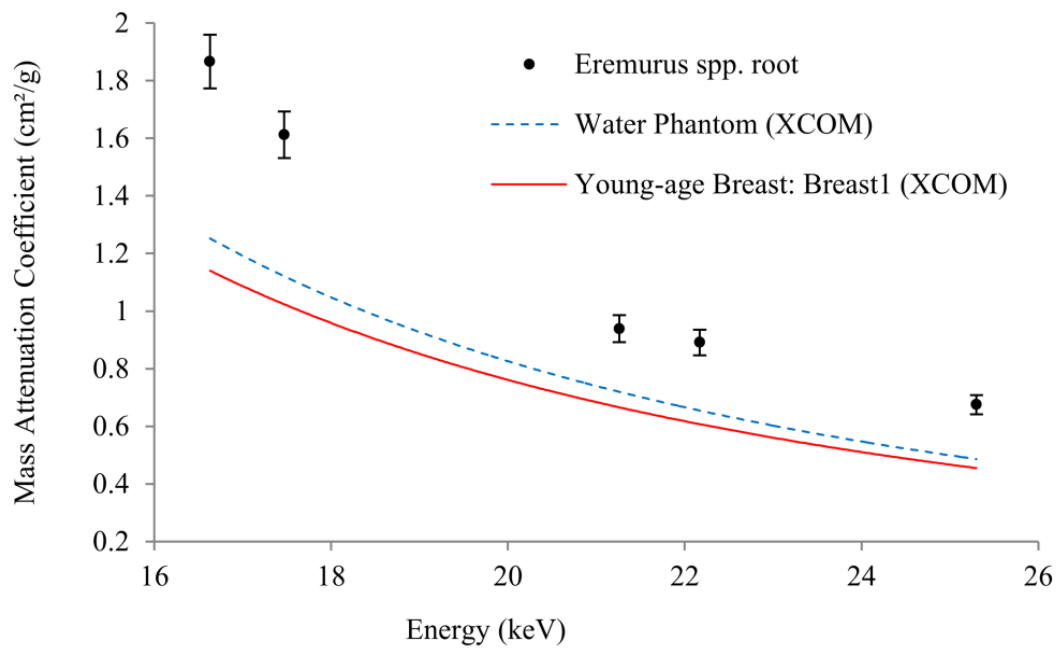

Figure 4. The comparison between the mass attenuation coefficients of the root of Eremurus with XCOM calculated that of water phantom and Breast 1 (Young-age breast).

According to Table 2 and Fig. 4, the mass attenuation coefficient of the root of Eremurus spp. was not close to that of water and Breast 1. Therefore, the Eremurus spp. root is not suitable to be a main and major phantom material in wooden mammography phantom. But, the weight percentage of the resin is around 5\% $15 \%$ in the particleboard [28]. So, the congruence and similarity of the mass attenuation coefficients of the root of Eremurus spp. with that of water and breast 1, caused that the root of Eremurus spp. had potential to be a binder material for the fabrication of particleboards.

\section{Conclusion}

The effective atomic number of the Eremurus spp. root was found much closer to those of breast tissue and water phantom. But, the mass attenuation coefficient of the root of Eremurus spp. was not the same as that of water and young-age breast. So the using of the root of Eremurus spp. was not found suitable as particles to fabricate particleboard phantom. But the results from XRF were found to be congruent, and compatible with that of water and breast tissue, which showed a suitability of the root of Eremurus spp. as a resin to fabricate particleboard phantom. 


\section{References}

[1] E.T. Tousi, R. Hashim, S. Bauk, M.S. Jaafar, A.M. Al-Jarrah, H. Kardani, A. Arra, A.M. Hamdan, K.S.A. Aldroobi, A Study of the Properties of Animal-Based Wood Glue, Advanced Materials Research, 935 (2014) 133-137.

[2] A. Abuarra, R. Hashim, S. Bauk, S. Kandaiya, E.T. Tousi, Fabrication and characterization of gum Arabic bonded Rhizophora spp. particleboards, Materials \& Design, 60 (2014) 108-115.

[3] A.M. Al-Jarrah, A.A. Rahman, I. Shahrim, N.N.A.N. Ab Razak, B. Ababneh, E.T. Tousi, Effect of inorganic salts and glucose additives on dose-response, melting point and mass density of genipin gel dosimeters, Physica Medica, 32 (2015) 36-41.

[4] A. Al-Jarrah, A.R. Azhar, S.M. Iskandar, N.N.A.N. Abrazak, B. Ababneh, E.T. Tousi, L.L. Soo, Effect of Sulfuric Acid Concentration on Radiological Properties of Genipin Gel Dosimeter, International Journal of Chemical, Environmental \& Biological Sciences, 2 (2014) 2320-4087.

[5] F.M. Khan, The physics of radiation therapy, Lippincott Williams \& Wilkins, Philadelphia, 2010.

[6] C.W.A.C.W. Sudin, A.A. Tajuddin, D.A. Bradley, Evaluation of tissue-equivalent media for dosimetric studies, Proceeding of local seminar activities on radiation physics, biophysics and medical physics, Universiti Malaya, Kuala Lumpur, Malaysia, 1988, pp. 71-80.

[7] B.Z. Shakhreet, S. Bauk, A.A. Tajuddin, A. Shukri, Mass attenuation coefficients of natural Rhizophora spp. wood for X-rays in the 15.77-25.27 keV range, Radiation Protection Dosimetry, 135 (2009) 47-53.

[8] M.W. Marashdeh, R. Hashim, A.A. Tajuddin, S. Bauk, O. Sulaiman, Effect of particle size on the characterization of binderless particleboard made from Rhizophora spp. Mangrove wood for use as phantom material, BioResources, 6 (2011) $4028-4044$.

[9] M.W. Marashdeh, S. Bauk, A.A. Tajuddin, R. Hashim, Measurement of mass attenuation coefficients of Rhizophora spp. binderless particleboards in the 16.59-25.26 keV photon energy range and their density profile using x-ray computed tomography, Applied Radiation and Isotopes, 70 (2012) 656-662.

[10] E.T. Tousi, R. Hashim, S. Bauk, M.S. Jaafar, A.M.H. Abuarra, B. Ababneh, Some properties of particleboards produced from Rhizophora spp. as a tissue-equivalent phantom material bonded with Eremurus spp, Measurement, 54 (2014) 14-21.

[11] A. Abuarra, S. Bauk, R. Hashim, S. Kandaiya, E.T. Tousi, B. Ababneh, XRF Technique for the Evaluation of Gum Arabic Bonded Rhizophora spp. Particleboards as Tissue Equivalent Material, International Journal of Applied Physics and Mathematics, 4 (2014) $201-204$. [12] E.T. Tousi, S. Bauk, R. Hashim, M.S. Jaafar, A. Abuarra, K.S.A. Aldroobi, A.M. Al-Jarrah, Measurement of mass attenuation coefficients of Eremurus-Rhizophora spp. particleboards for X-ray in the 16.63-25.30 keV energy range, Radiation Physics and Chemistry, 103 (2014) 119-125.

[13] E.T. Tousi, R. Hashim, S. Bauk, M.S. Jaafar, A.M.H. Abuarra, A.M. Al-Jarrah, B. Ababneh, A.T. Tousi, K.S.A. Aldroobi, Characterization of the Rhizophora Particleboard as a Tissue-Equivalent Phantom Material Bonded with Bio-Based adhesive, Maderas: Ciencia y tecnología, 17 (2015).

[14] E.T. Tousi, M.M. Firoozabadi, M. Shiva, Determination of the thorium potential in Shah-Kooh area in Iran by NAA and comparison with the results of ICP and XRF techniques, Measurement, 90 (2016) 20-24.

[15] I.O. Olarinoye, Variation of Effective Atomic Numbers of some Thermoluminescence and Phantom Materials with Photon Energies, Research Journal of Chemical Sciences, 1 (2011) 64-69.

[16] E.T. Tousi, H. Kardani, M.M. Firuzabadi, M.S. Jaafar, A.M. Al-jarrah, L. Ghasemi, P. Moradi Khaniabadi, Y.A. Amin, Shielding of Am-Be Neutron Source by Using MCNP4C Code and Real Dosimetry, Caspian Journal of Applied Sciences Research, 3 (2014) 13-22.

[17] J. Beutel, H.L. Kundel, R.L. Van Metter, Handbook of Medical Imaging, volume 2: Physics and Psychophysics, SPIE Press, Bellingham, Washington, 2000.

[18] P. Hertrich, Practical Radiography: principles and applications, John Wiley \& Sons, 2005.

[19] M.F. L'Annunziata, Radioactivity: Introduction and History, Elsevier, Amsterdam, 2007.

[20] M.J. Berger, J. Hubbell, XCOM, Photon cross sections on a personal computer, U.S. Department of Commerce, 1987.

[21] F.H. Attix, Introduction to radiological physics and radiation dosimetry, Wiley-VCH, New York, 2008.

[22] L.L. Gunderson, J.E. Tepper, Clinical radiation oncology, Third ed., Saunders, Elsevier Inc., Philadelphia, 2007.

[23] C.M. Tsai, Z.H. Cho, Physics of contrast mechanism and averaging effect of linear attenuation coefficients in a computerized transverse axial tomography (CTAT) transmission scanner, Physics in Medicine and Biology, 21 (1976) 544-559.

[24] P. Duvauchelle, G. Peix, D. Babot, Effective atomic number in the Rayleigh to Compton scattering ratio, Nuclear Instruments and Methods in Physics Research Section B: Beam Interactions with Materials and Atoms, 155 (1999) 221-228.

[25] S. Bauk, A.A. Tajuddin, Attenuation Coefficient of Rhizophora spp. in the 11.22 to 28.43 keV Photon Energy Range, Journal of Nuclear and Related Technologies, 5 (2008) 11-19.

[26] S.R. Mitkar, S.M. Dongarge, To study the linear and mass attenuation coefficient of alcohol soluble compound for gamma rays at energy $662 \mathrm{KeV}$, Journal of Chemical and Pharmaceutical Research, 4 (2012) 3944-3949.

[27] AAPM-21, Protocol for the determination of absorbed dose from high-energy photon and electron beams: Task Group 21, medical physics, 10 (1983) 741-771.

[28] N. MacDonald, Woodworking, Cengage Learning, New York, 2013. 